DOI https://doi.org/10.18551/rjoas.2018-06.57

\title{
BIOACTIVE CONTENT IDENTIFICATION OF BULUBANGKAL LEAF (NAUCLEA SUBDITA [KORTH.] STEUD.) AND IT'S ANALYSIS AS AEROMONAS HYDROPHILA ANTIBACTERIAL BY IN VITRO AND IN SILICO METHODS
}

\author{
Aisiah Siti* \\ Postgraduate Program, Faculty of Fisheries and Marine Science, \\ University of Brawijaya, Indonesia \\ Prajitno Arief, Maftuch, Ating Yuniarti \\ Department of Fisheries Product Technology, Faculty of Fisheries and Marine Science, \\ University of Brawijaya, Indonesia \\ *E-mail: sitiaisiahbp@gmail.com
}

\begin{abstract}
This research aimed at finding out a bioactive content of bulubangkal leaf and extractability of 3 polar solvents, semi-polar and non-polar as Aeromonas hydrophila antibacterial. The sample was extracted by maceration and fractionation methods using $\mathrm{n}$-hexane solvent, ethyl acetate, and methanol. Antibacterial activity was carried out by disk-diffusion agar method. It was found that active agent contained within bulubangkal leaf are saponin, tannin, phenolic, and steroid as A. hydrophilia bacterial based on the antibacterial test by in vitro and in silico methods.
\end{abstract}

\section{KEY WORDS}

Phytochemistry, antibacterial, Nauclea subdita, Aeromonas hydrophila.

Indonesia is the second largest country in the world after Brazil to have biological diversity. A plant is a home of various active agent content-rich chemical compounds, among others secondary metabolic products function to the process of metabolism. This compound group plays an important role in the process of interaction or competition, including defending self from pests and diseases attack. At a swampland is found more than 1000 kinds of a plant which can be used as a material of pest controller such as biopesticides material (Asikin, 2015).One of the swamp plants frequently utilized as an alternative medicine is the bulubungkal; it commonly results in a secondary metabolic compound such as tannin, phenolic, steroid, and alkaloids (Liew et al., 2012). People commonly utilize bulubangkal to reverse injury; it is applied to the surface of ulcer and tumor, the water of the boiled leaf functions to reverse diarrhea and toothache. N. subdita also contains antioxidant and steroid working for cells growth so almost all of the Banjar utilizes it as the raw material of anti-acne powder and to soften skin face in which steroid compound has an ability to rejuvenate damaged cells.

Bioactive compound contained within Nuclea subdita is a type of secondary metabolic such as tannin, alkaloid, and phenolic which can be used as a natural bactericide. Leaf, flesh, and root of N. Subdita are found to contain alkaloid, tannin and phenolic and saponin (Amos et al., 2005). Some phytochemistry such as tannin, alkaloid, and flavonoid has shown pathogen antibacterial within fish(Haniffa \& Kavitha, 2012). This research made an identification of bioactive content and antibacterial test of bulubangkal leaf towards Aeromonas hydrophila bacterial which is pathogen bacterial contained within fish especially fresh water by in vitro and in silico methods.

\section{MATERIALS AND METHODS OF RESEARCH}

The materials used to conduct this research were bulubangkal leaf, methanol (polar), ethyl acetate (semi-polar), n-hexane (non-polar) all of them with PA grade, active extract of 
bulubangkal leaf, TLC plate. A set of tools used are among others Miyako BL-152 GF blender made in Indonesia, a rotary evaporator (IKA RV 10 Digital V made in Germany), erlenmayer flask, mixer, measuring cylinder, lint, silica gel, aluminum sheet, etc. While the equipment is TLC vessel, oven, splattering, UV lamp, glassware, UV-Vis.

N. subdita (Korth). Steud. leaf was cleaned, cut into small pieces and dried by being aerated. The dried leaves were then mashed with a blender until becoming soft powder. It was then given phytochemistry test towards the sample and conducted maceration. 50 grams of N. subdita (Korth). Steud. powder was soaked in $200 \mathrm{ml}$ methanol, ethyl acetate and n-hexane for 2x24 hours in an erlenmayer screw cap, the next step was being separated between extract and waste, repeated for $3 x$ with the same solvent. The extract collected was then evaporated using vacuum rotary evaporator at the temperature of $40^{\circ} \mathrm{C}$ until there is no solvent condensation anymore at the condenser. It was then being baked for 3 hours under the temperature of $45^{\circ} \mathrm{C}$ aiming at relieving solvent still trapped in the bioactive extract, its waste was dried and then its final weight was weighed. A thick extract was the last one will use to conduct an antibacterial test.

This test is used to find out what solvent most effective to use as extracting of $\mathrm{N}$. subdita (Korth). Steud. bioactive which is antibacterial in nature using disk method, that is an antimicrobial examination by measuring the diameter of obstacle area happens along the disk paper under the diameter of $6 \mathrm{~mm}$, which has been given N. subdita (Korth). Steud. extract. Extract from the solvent giving the biggest drag zone was selected active extract.

The last extract that has been concentrated with gas $\mathrm{N}_{2}$, taken only $0.1 \mathrm{ml}$ and then diluted in $10 \mathrm{~mL}$ volumetric flask with applicable solvent. This solution was then entered into absorption cuvettes and its uptake reads using spectrophotometer UV which has been calibrated using proper solvent blanks in advance. The uptake is read at the wave length of $200-400 \mathrm{~nm}$.

Pure isolates identification with spectrophotometer FTIR is used to take 2 gram solids of freewater $\mathrm{KBr}$ and the mashed and pressed at 2 torr pressure. $\mathrm{KBr}$ pellet was added by 1 drop of isolate, then analyzed using spectrophotometer FT-IR over the $4000-8000 \mathrm{~cm}^{-1}$ range.

Active isolate analyzed using GC-MS, carrier gas used is helium with regulated stream below: Injector temperature is $320^{\circ} \mathrm{C}$, initial temperature is $70^{\circ} \mathrm{C}$. Increase rate of temperature is $10^{\circ} \mathrm{C}$, and the last temperature in oven is $310^{\circ} \mathrm{C}$.

In Silico Analysis - using PASS prediction method, that is GCMS result search using software Pass Online (WAY2DRUG).

\section{RESULTS AND DISCUSSION}

Identification result of bulubangkal plant used in this research was undertaken at Research Center for Biology in Cibinong, Bogor. Identity result revealed that this plant is categorized into the family of Rubiacease and species (Nauclea subdita [Korth.] Steud.).

Phytochemistry Test Result

Table 1 - Phytochemistry test result of bulobangkal leaf

\begin{tabular}{lll}
\hline No. & Secondary Metabolic & Test Result \\
\hline 1 & Phenolic & ++ \\
2 & Flavonoid & - \\
& $\bullet \quad$ Reagen $\mathrm{HCL}_{\text {concentrated }+\mathrm{Mg}}$ & + \\
& $\bullet \quad$ Reagen $\mathrm{H}_{2} \mathrm{SO}_{4} 2 \mathrm{~N}$ & - \\
3 & $\bullet \quad$ Reagen $\mathrm{NaOH} \mathrm{10 \%}$ & \\
& Alkaloid: & - \\
& $\bullet \quad$ Reagen Mayer & - \\
& $\bullet \quad$ Reagen Wagner & - \\
5 & $\bullet \quad$ Reagen Hager & + \\
6 & Steroid & + \\
7 & Triterpenoid & ++ \\
\hline
\end{tabular}


According to the result of phytochemistry test above, bulubangkal leaf contains saponin, tannin, phenolic, flavonoid, triterpenoid, and steroid. Phenolic and flavonoid contained within the plant are known to have an important role in antioxidant activity test. The higher the phenolic content in the sample, the higher the activity of its antioxidant, (Trisharyanti,et al., 2011).

Tanin is a secondary metabolic compound contained within a plant. Tanin is polyphenol derivative with a characteristic which is able to form a complex compound with other macromolecules. Tannin is commonly soluble in the polar solvent. Chemically, there are two types of tannin, i.e. condensed tannin and hydrolized tannin. Condensed tannin is widely spread on woody plants and ferns, while the spread of hydrolized tannin is limited to dicotyledon (Auni, et al., 2013). According to Akiyama, et al., 2001, at the activity of antimicrobial, tannin has a positive effect on the different bacterial strain.

Tannin and saponin are proven to have anthelminthic activity (pal, et al., 2007). Tannin found functions to tie independent protein in the digestive tract of the host or glycoprotein in the parasitic cuticle and will cause death (Mali \& wadekar, 2008). Benefit and effect potential of tannin, such as antimicrobial and antioxidant in nature. Tannin also has a physiological effect such as accelerating blood clots, and decreasing cholesterol content and lipid also blood as well as ability to act as anticancer (Chung, et al., 1998). An observation to utilize several sources containing tannin, food of several fish species show low lipid deposit in the digestive tract (Hossain, et al., 2001). Tannin has shown antibacterial (Banso \& Adeyeme, 2007). Tannic acid can disturb microorganism growth by forming a complex with surface protein (Bhat, et al., 1998).

Saponin causes stimulus on a particular tissue, nasal epithelium, bronchus, kidney, etc. Stimulation on the kidney is expected to cause diuretics effect. Saponin can increase a respond of various substances from surface activity, saponin is also able to stretch insoluble particle and to assign that particle spread and divide softly into the solvent (Sartini, et al, 2012).

The test result of drag power of bulubangkal leaf towards A. hydrophila bacterial by disk method, drag zone resulted can be seen in Table 2.

Table 2 - Drag zone test result of bulubangkal leaf towards A. hydrophila bacterial growth after 24 hours

\begin{tabular}{|l|l|l|}
\hline No & Sample & Drag Zone $(\mathrm{mm})$ \\
\hline 1 & Bulubangkal leaf - methanol & $17.83 \pm 0.28$ \\
\hline 2 & Bulobangkal leaf-ethyl acetate & $23.33 \pm 0.57$ \\
\hline 3 & N-hexane & - \\
\hline 4 & Gentamicin control & $21.66 \pm 0.57$ \\
\hline
\end{tabular}

Antibacterial test result after 24 hour shows that the biggest drag zone of ethyl acetate fraction is $23.33 \pm 0.57 \mathrm{~mm}$, followed by methanol fraction with drag zone of $17.83 \pm 0.28$ $\mathrm{mm}$. While n-hexane fraction has no drag zone from the initial observation until the last, gentamicin control of $21.66 \pm 0.57 \mathrm{~mm}$. Ethyl acetate fraction (semi-polar solvent) is able to dissolve active agent well contained within bulubangkal leaf compared to methanol (polar solvent) and n-hexane (non-polar solvent). Control actually has bigger drag zone than a treatment but at 72 hours bactericidal zone decreases and more decreases at 96 hours observation.

Drag zone formed shows an active agent ability contained within bulubangkal leaf using semipolar and polar solvent, it is expected that tannin contained within bulobangkal leaf has an antibacterial ability, in which tannin activity has been reported as bacteriostatic and bactericidal including A. hydrophilla, E. coli, Listeria, Pseudomonas, Salmonella, Staphylococaccus and Streptococaccus (Chung et al., 1998). A complex capability of polyphenol and polymer as well as mineral have inhibition effect towards bacteria. Tannin contained within bulubangkal leaf also contains toxic characteristic and hamper enzyme in microbe (Bossi et al., 2007). 
UV-VIS test Result. Analysis result of UV-VIS shows 6 spectrums of wavelength over the 200 until $800 \mathrm{~nm}$, with maximum peak spectrum of $222 \mathrm{~nm}$ and 206nm. The occurrence of strong uptake at ultraviolet spectrum shows the existence of the number of double bonds $\mathrm{C}=\mathrm{C}$ in the friction compound of bulubangkal leaf. This strong uptake indicates phenol compound and its derivative.

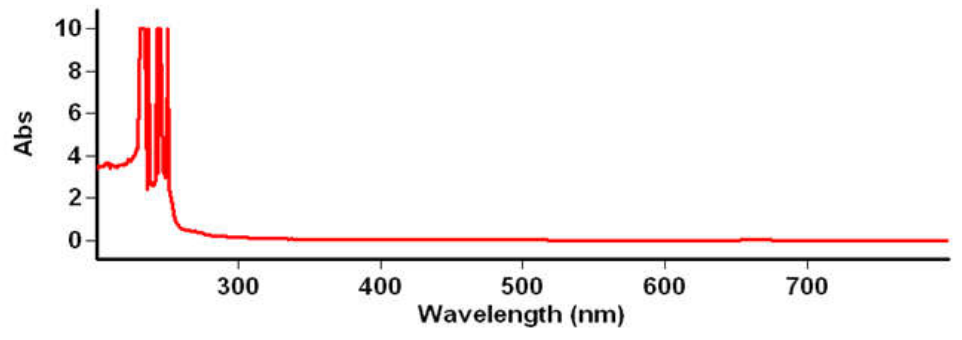

Figure 1 - Results of spectroscopy analysis

Spectroscopy analysis result of infrared shows the existence of $-\mathrm{OH}$ bending with widened bond at number absorption.

Table 3 - Extract components of bulubangkal leaf based on the result of UV-VIS

\begin{tabular}{lllll}
\hline No & UV-VIS result & $\begin{array}{l}\text { Literature } \\
\text { Rojas \& Ojeda, (2009\&2013) }\end{array}$ & Component & PubChem CID \\
\hline 1 & 239.0 & 239.0 & Citalopram $\left(\mathrm{C}_{20} \mathrm{H}_{21} \mathrm{FN} \mathrm{F}_{2} \mathrm{O}\right)$ & 2771 \\
2 & 222.0 & $217.4-223.0$ & Fosinopril $\left(\mathrm{C}_{30} \mathrm{H}_{46} \mathrm{NO}_{7} \mathrm{P}\right)$ & 55891 \\
3 & 215.0 & 215 & Vincamine $\left(\mathrm{C}_{21} \mathrm{H}_{26} \mathrm{~N}_{2} \mathrm{O}_{3}\right)$ & 15376 \\
4 & 212 & 212 & Tocopherol acetate $\left(\mathrm{C}_{31} \mathrm{H}_{52} \mathrm{O}_{3}\right)$ & 86472 \\
5 & 209.9 & 209.9 & Piracetam $\left(\mathrm{C}_{6} \mathrm{H}_{10} \mathrm{~N}_{2} \mathrm{O}_{2}\right)$ & 4843 \\
6 & 206.9 & $200-210$ & Ramiopril $\left(\mathrm{C}_{23} \mathrm{H}_{32} \mathrm{~N}_{2} \mathrm{O}_{5}\right)$ & 5362129 \\
\hline
\end{tabular}

FTIR test result of ethyl acetate extract of bulubangkal leaf having 9 absorption bonds can be seen in Figure 2.

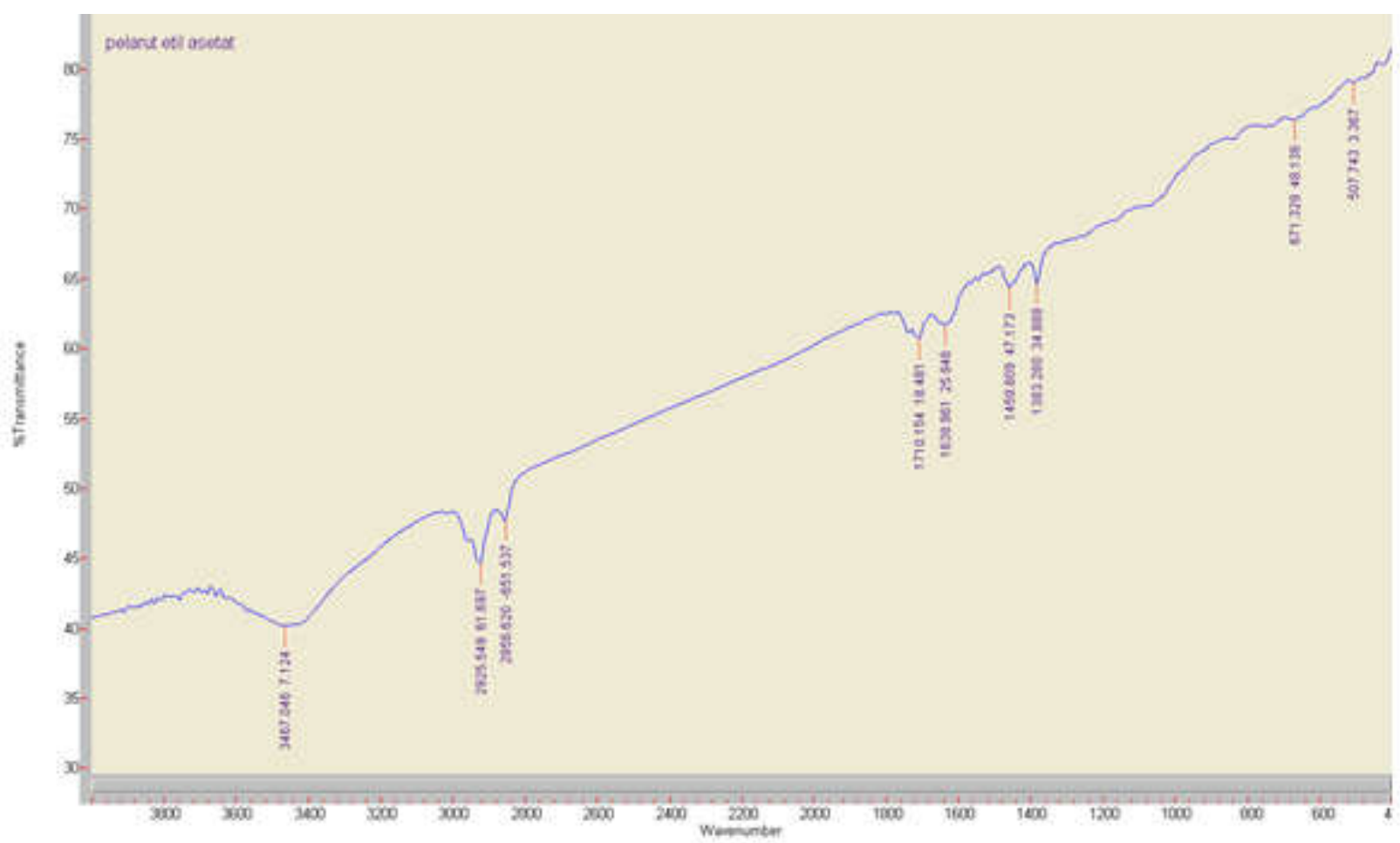

Figure $2-H T I R$ test result towards bulubangkal leaf extract 
According to figure 2 ethyl acetate fraction compound of bulubangkal leaf extract contains ionic fractions as listed in the following table.

Table 3 - Absorption band, wave number, vibration type and band form of FTIR result of bulobangkal leaf extract

\begin{tabular}{lllll}
\hline Absorption bond & $\begin{array}{l}\text { Wave Number } \\
\left(\mathrm{cm}^{-1}\right)\end{array}$ & Reference(Harborne, 2006) & Vibration type & Bond form \\
\hline 1 & 3467 & $3500-3200$ alcohol & $-\mathrm{OH}$ bending & Widened \\
2 & 2926 & $3000-2700$ & $-\mathrm{C}-\mathrm{H}\left(\mathrm{SP}^{3}\right)$ stretching aliphatic & Weak \\
3 & 2856 & $3000-2700$ & $-\mathrm{C}-\mathrm{H}\left(\mathrm{SP}^{3}\right)$ stretching aliphatic & Weak \\
4 & 1710 & $2100-1700$ & aromatic $\mathrm{C}=\mathrm{H}$ stretches & Weak \\
5 & 1638 & $1670-1475$ & $-\mathrm{C}=\mathrm{C}-$ aromatic & average \\
6 & 1459 & $1470-1450$ & $-\mathrm{CH}_{2},-\mathrm{CH}_{3}$ scissoring & Weak \\
7 & 1383 & -1050 & $-\mathrm{OH}$ primer & Average \\
8 & 671 & $690-590$ & $-\mathrm{C}=\mathrm{CH}$ out of plane & Weak \\
9 & 507 & $-570-540$ & monobranched alkanes $\left(-\mathrm{CH}_{3}\right)$ & Weak \\
\hline
\end{tabular}

According to the result of GCMS test conducted to the ethyl acetate extract of bulubangkal leaf is obtained a graph as follows:

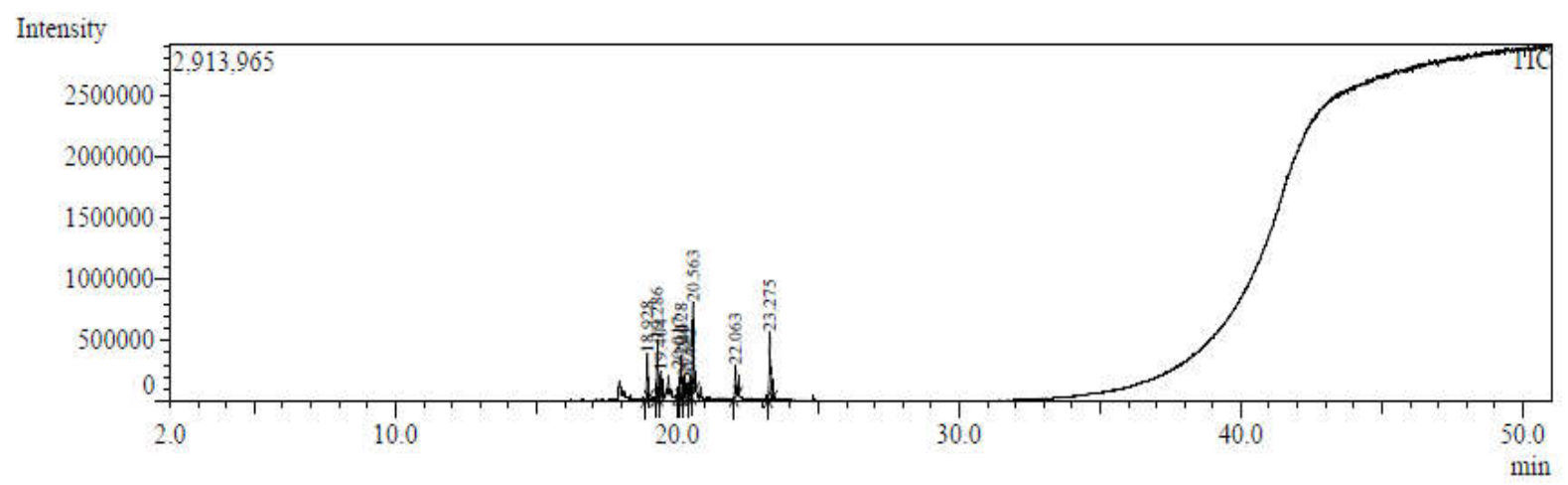

Figure 3-GCMS analysis result of ethyl acetate extract of bulubangkal leaf

According to the figure above, it can be known that there is a different point, among other, there are 9 highest points. Of the point received, based on the literature review, is expected that the compound contained within bulubangkal leaf extract as follows.

Table 4 - Compound contained within bulobangkal leaf based on the library (PubChem)

\begin{tabular}{|c|c|c|c|c|c|}
\hline $\mathrm{n} / \mathrm{n}$ & Point & Name & Formula & Compound Structure & PubChem (CID)/BM \\
\hline$n / n$ & 1 & 2 & 3 & 4 & 5 \\
\hline 1 & 18.925 & Beta-caryophyllene & $\mathrm{C}_{15} \mathrm{H}_{24}$ & & $\begin{array}{c}5281515 / \\
204.357 \mathrm{~g} / \mathrm{mol}\end{array}$ \\
\hline 2 & 19.283 & Alpha guaiene & $\mathrm{C}_{15} \mathrm{H}_{24}$ & & $\begin{array}{c}5317844 / \\
204.357 \mathrm{~g} / \mathrm{mol}\end{array}$ \\
\hline 3 & 19.400 & Seychellene & $\mathrm{C}_{15} \mathrm{H}_{24}$ & & $\begin{array}{c}519743 / \\
204.357 \mathrm{~g} / \mathrm{mol}\end{array}$ \\
\hline 4 & 20.125 & Alpha panasinsen & $\mathrm{C}_{15} \mathrm{H}_{24}$ & & $\begin{array}{c}578929 / \\
204.357 \mathrm{~g} / \mathrm{mol}\end{array}$ \\
\hline
\end{tabular}




\begin{tabular}{|c|c|c|c|c|c|}
\hline $\mathrm{n} / \mathrm{n}$ & 1 & 2 & 3 & 4 & 5 \\
\hline 5 & 20.558 & Alpha-patchoulene & $\mathrm{C}_{15} \mathrm{H}_{24}$ & & $\begin{array}{c}521710 / \\
204.357 \mathrm{~g} / \mathrm{mol}\end{array}$ \\
\hline 6 & $20.550-20.567$ & - & $\mathrm{C}_{15} \mathrm{H}_{24}$ & & $\begin{array}{c}11095734 / \\
204.357 \mathrm{~g} / \mathrm{mol}\end{array}$ \\
\hline 7 & $20.443-20.450$ & Allo-aromadendrene & $\mathrm{C}_{15} \mathrm{H}_{24}$ & & $42608158 / 204.357 \mathrm{~g} / \mathrm{mol}$ \\
\hline 8 & 20.442 & Longifolene & $\mathrm{C}_{15} \mathrm{H}_{24}$ & & $204.357 \mathrm{~g} / \mathrm{mol}$ \\
\hline 9 & $20.443-20.450$ & Alpha-Bulnesene & $\mathrm{C}_{15} \mathrm{H}_{24}$ & & $\begin{array}{c}94275 / \\
204.357 \mathrm{~g} / \mathrm{mol}\end{array}$ \\
\hline
\end{tabular}

According to the result above, the compound contained within bulobangkal leaf has a formula and similar molecular weight of $\mathrm{C}_{15} \mathrm{H}_{24}$, with molecular weight of $204.357 \mathrm{~g} / \mathrm{mol}$, but having different compound structure.

According to the result of compound identification using GCMS is known 9 active compounds of Bulobungkal leaf which its potential is then analyzed using WAY2DRUG PASS prediction as antimicrobial and antifungal, etc, demonstrated in the following table as antibacterial, antibiotic, antiseptic, antiparasitic, and Peptidoglycan glycosyltransferase inhibitor.

Table 4 - Compound content in bulubangkal leaf based on in silico analysis

\begin{tabular}{|c|c|c|c|c|c|}
\hline Compound & Antibacterial & Antibiotic & Antiseptic & Antiparasitic & $\begin{array}{c}\text { Peptidoglycan } \\
\text { glycosyltransferase inhibitor }\end{array}$ \\
\hline Beta-caryophyllene & 0.437 & & & 0.382 & 0.397 \\
\hline Alpha guaiene & 0.306 & & & 0.414 & 0.482 \\
\hline Seychellene & & & & 0.401 & 0.589 \\
\hline Alpha panasinsen & 0.33 & & & & 0.566 \\
\hline Methandrostenolone & & & & & 0.562 \\
\hline Alpha-patchoulene & 0.356 & & & 0.477 & 0.457 \\
\hline Allo-aromadendrene & 0.38 & & & & 0.471 \\
\hline Longifolen & & & & 0.355 & 0.391 \\
\hline Alpha-Bulnesene & 0.34 & & & & \\
\hline
\end{tabular}

Assessment result of $\mathrm{Pa}$ value for a particular activity such as antibacterial, antibiotic, antiseptic, antiparasitic, and peptiidoglikan glikosiltransferaseinhibitor (playing role as cell cycle, cell form, and cell wall). $\mathrm{Pa}$ (probability To Be Active) value is a value reflecting a potential of a compound tested. An active agent of bulubangka leaf has various values. If $\mathrm{Pa}$ value above 0,7 so the compound is predicted to have a high potential as antimicrobial computationally and through laboratory test method. While if $\mathrm{Pa}$ value is more than 0.3 or less than 0.7 so the compound has computationally ability as antimicrobial and antifungal, but in a laboratory test way is not proven or its potential is small. 


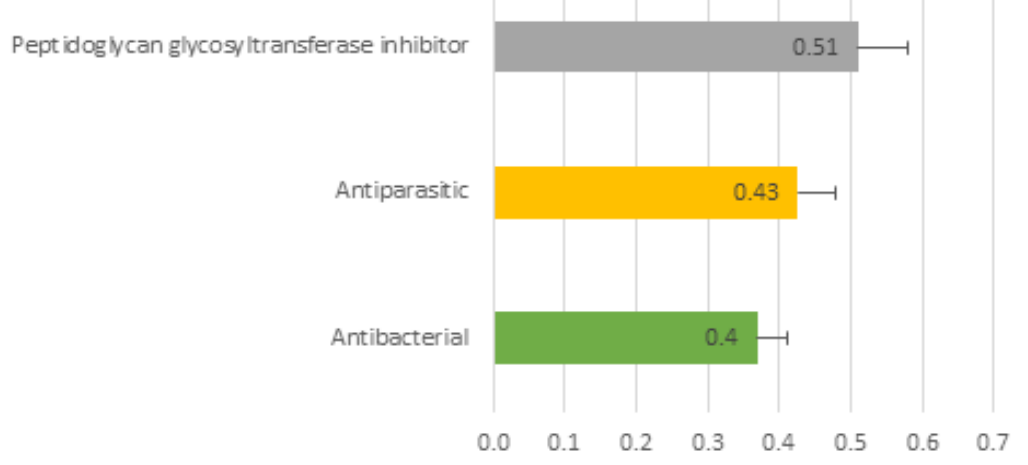

Figure 4 - Pa value of Bulubangka leaf

According to that $\mathrm{Pa}$ value above, an active agent of bulubangka leaf has a computational potential as antibacterial but its potential needs to be proven in a laboratory way since its score probability to be active is under 0.7 . Trial result of in vitro method is proven that bulubangka leaf extract has a big drag zone towards A. hydrophila bactery, ethyl acetate extract of $23.88 \pm 0.74 \mathrm{~mm}$ and methanol of $17.03 \pm 0.48 \mathrm{~mm}$. Peptidoglycan $(P G)$ is an important macromolecule like a tissue surrounding bacteria, giving them the form, and protecting them from its osmotic pressure. PG inhibition of synthesis causes bacterial cell lysis (Derouaux, et al., 2013) This inhibition of synthesis of the cell wall is like a medicine containing $\beta$ lactam, working procedure of inhibition was initiated by medicine binding of cell receptor-like transpeptidase enzyme among other. After adhesion at one or more receptor, reaction happened is a transpeptidase enzyme reaction and hampered peptidoglycan synthesis leading to the activity termination of autolysis on cell wall, and furthermore lysis enzime becomes active (jaweltz, et al., 2001).

\section{CONCLUSION}

Bulubangka leaf has a computational potential as antibacterial under 0.7 , it is proven by in vitro method of ethyl acetate fraction and effective methanol fraction hampering $A$. hydrophila bacterial while $n$-hexane fraction does not effectively hamper. It concludes that bulubangka leaf contains bioactive in form of saponin, tannin, phenolic, flavonoid, and steroid used as A. hydrophilia antibacterial.

\section{REFERENCES}

1. Abbah, J., Amos, S., Chindo, B., Ngazal, I., Vongtau, H. O., Adzu, B., Gamaniel, K. S. (2010). Pharmacological evidence favouring the use of Nauclea latifolia in malaria ethnopharmacy: Effects against nociception, inflammation, and pyrexia in rats and mice. Journal of Ethnopharmacology, 127(1), 85-90. http://doi.org/10.1016/j.jep.2009.09.045

2. Aisiah, S. (2012). Potensi Tumbuhan Bangkal ( Nauclea orientalis ) Untuk Pengendalian Bakteri Aeromonas Hydrophila. Fish Scientiae, 2(4), 166-177.

3. Akiyama, H., Fujii, K., Yamasaki, O., Oono, T., \& Iwatsuki, K. (2001). Antibacterial action of several tannins against Staphylococcus aureus. J Antimicrob Chemoth, 48(4), 487491. http://doi.org/10.1093/jac/48.4.487

4. Amos, S., Abbah, J., Chindo, B., Edmond, I., Binda, L., Adzu, B., Gamaniel, K. (2005). Neuropharmacological effects of the aqueous extract of Nauclea latifolia root bark in rats and mice. Journal of Ethnopharmacology, 97(1), 53-57. http://doi.org/10.1016/j.jep.2004.10.003

5. Asikin, S. (2015). Biopestisida sebagai Kearifan Lokal dalam Mengendalikan Hama untuk Menunjang Pertanian Organik. Balai Penelitian Pertanian Lahan Rawa (Balittra) Jl. Kebun Karet PO BOX 31, Loktabat Utara, Banjarbaru, Indonesia.

6. Auni, N., Abidin, Z., Huda, N., Halim, A., \& Me, R. (2013). Basic Study of Chemical 
Constituents in Rhizophora Species, 27-28.

7. Banso, a, \& Adeyemo, S. O. (2007). Evaluation of antibacterial properties of tannins isolated from Dichrostachys cinerea. African Journal of BiotechnologyJournal of Biotechnology, 6(15), 1785-1787.

8. Bhat, T.K. (1998). Microbial degradation of tannins--a current perspective. Biodegradation, 9(5), 343-357. http://doi.org/10.1023/a:1008397506963

9. Bossi, A., Rinalducci, S., Zolla, L., Antonioli, P., Righetti, P. G., \& Zapparoli, G. (2007). Effect of tannic acid on Lactobacillus hilgardii analysed by a proteomic approach. Journal of Applied Microbiology, 102(3), 787-795. http://doi.org/10.1111/j.13652672.2006.03118.x

10. Chung, K. T., Wong, T. Y., Wei, C. I., Huang, Y. W., \& Lin, Y. (1998). Tannins and human health: a review. Critical Reviews in Food Science and Nutrition, 38(6), 421-464. http://doi.org/10.1080/10408699891274273

11. Derouaux, A., Sauvage, E., \& Terrak, M. (2013). Peptidoglycan glycosyltransferase substrate mimics as templates for the design of new antibacterial drugs, 4(March), 1-6. http://doi.org/10.3389/fimmu.2013.00078

12. Haniffa, M. A., \& Kavitha, K. (2012). Antibacterial activity of medicinal herbs against the fish pathogen Aeromonas hydrophila, 8(1), 205-211.

13. Harborne, J. (2006). Metode Fitokimia. Penuntun Cara Modern Menganalisis Tumbuhan. (K. Padmawinata \& Soediro, Eds.). Bandung: Penerbit ITB. Bandung.

14. Hossain, M. A., Focken, U., \& Becker, K. (2001a). Effect of soaking and soaking followed by autoclaving of Sesbania seeds on growth and feed utilisation in common carp, Cyprinus carpio L. Aquaculture, 203(1-2), 133-148. http://doi.org/10.1016/S00448486(01)00616-0

15. Hossain, M. A., Focken, U. (2001b). Evaluation of an unconventional legume seed, Sesbania aculeata, as a dietary protein source for common carp, Cyprinus carpio L. Aquaculture, 198(1-2), 129-140. http://doi.org/10.1016/S0044-8486(00)00574-3

16. Jaweltz, E., Melnick, \& Adelberg. (2001). Medical Microbiolog (22nd ed.). McGraw-Hill Company. USA.

17. Liew, S. Y., Mukhtar, M. R., Hadi, A. H. A., Awang, K., Mustafa, M. R., Zaima, K., ... Litaudon, M. (2012). Naucline, a new indole alkaloid from the bark of Nauclea officinalis. Molecules, 17(4), 4028-4036. http://doi.org/10.3390/molecules17044028

18. Mali, R. G., \& Wadekar, R. R. (2008). In Vitro Anthelmintic Activity of Baliospermum montanum Muell. Arg roots. Indian Journal of Pharmaceutical Sciences, 70(1), 131-133. http://doi.org/10.4103/0250-474X.40352

19. Ojeda, C. B., \& Rojas, F. S. (2013). Recent applications in derivative ultraviolet / visible absorption spectrophotometry: $2009-2011$ A review, 106, 1-16. http://doi.org/10.1016/j.microc.2012.05.012

20. Pal, D. K., Sahoo, M., \& Mishra, A. . (2007). Anthelminthic Activity Of Stems Of Opuntia vulgaris Mill. Asian Journal Of Chemistry, 19(1), 793-795.

21. Rojas, F. S., \& Ojeda, C. B. (2009). Analytica Chimica Acta Recent development in derivative ultraviolet / visible absorption spectrophotometry : $2004-2008$ A review, 635, 22-44. http://doi.org/10.1016/j.aca.2008.12.039

22. Sartini, Djide, M.N. (2012). Ekstraksi komponen bioaktif dari limbah kulit buah kakao dan pengaruhnya terhadap aktivitas antioksidan dan antimikroba extraction bioactive compound from cocoa pod husk and its effect on antioxidant and antibacterial activity.

23. Trisharyanti, I., Kusumowati, D., Melannisa, R., \& Ratri, K. (2011). Korelasi kandungan fenolik dan aktivitas antioksidan daun jambu mete, 3, 25-30. 